Универзитет у Нишу, Филозофски факултет, Департман за филозофију, Ниш, Србија

DOI: https://doi.org/10.46630/gsoc.23.2019.06

\title{
КРАТАК УВОД У РЕЦЕПЦИЈУ „ФРАНЦУСКЕ ТЕОРИЈЕ“
}

Књига Кратак увод у рецепичиу „франиуске теорије“ је збирка текстова посвећених различитим начинима на које је, пре свега у Сједињеним Америчким Државама и Европи, али и широм света, прихваћена специфична теоријска оријентација коју негују теоретичари пупут Жака Дериде (Jacques Derrida), Мишела Фукоа (Michel Foucault) и Жила Делеза (Gilles Deleuze), а која је на тлу америчког континента названа „француском теоријом“(енг. French Theory). Књигу је приредио Дејан Аничић, главни уредник издавачке куће Карпос, а уједно и аутор превода првог дела текста Стенлија Фиша (Stanley Fish) „Француска теорија у Америци“. Поред Аничића, преостале текстове у књизи превели су Оља Петронић, Миљана Протић, Милана Бабић и Елеонора Прохић.

На самом почетку ове књиге налазимо два текста у којима се непосредно приступа проблематици рецепције француске теорије. О афирмацији коју је ова теоријска оријентација доживела у Сједињеним Америчким Државама најпре говори Франсоа Кисе (François Cusset), аутор познате књиге French Theоry: Фуко, Дерида, Делез \& Со и преображаји интелектуалног живота y Сједиъеним Државама, у посебном уприличеном интервјуу за издање часописа Contemporary French and Francophone Studies посвећеном француској теорији (DalMolin \& Célestin 2014). Да је издавачка кућа Карпос имала и посебан повод за објављивање књиге о рецепцији француске теорије, показује и чињеница да је у њеном издању, годину дана раније, изашао и српски превод поменуте Кисеове књиге. У интервјуу француски теоретичар истиче неке од основних мотива подробно обрађених у књизи о француској теорији - разлоге због којих је француска теорија доживела успех у Америци и због којих се, према аутору, може сматрати „америчким изумом“, као и објашњење због чега је она дуго занемаривана у матичној Француској (Аничић 2018: 7). Без обзира на извесну терминолошку неусаглашеност овог интервјуа и осталих текстова у књизи, будући да се „француска теорија“ у њему именује енглеским речима „French Theory“, док у осталим текстовима ову формулацију налазимо у преведеном облику, што изазива одређене недоумице да ли је заправо на тим местима реч о Кисеовој књизи или о специфичном теоријском опредељењу, овај интервју функционише као одличан темељ за разумевање већине других текстова у књизи, што ће бити видљиво у наставку приказа.

\footnotetext{
${ }^{1}$ dusan.milenkovic@filozofski.rs
} 
У књизи о рецепцији француске теорије налазимо још један текст објављен у издању часописа Contemporary French and Francophone Studies посвећеном француској теорији. У овом случају, о специфичном теоријском усмерењу које негују француски теоретичари говори професор америчког универзитета Корнел и познати тумач структуралистичке традиције, Џонатан Калер (Jonathan Culler). Текст који носи назив „Нови осврт на француску теорију“ (Culler 2014) вешто је позициониран након Кисеовог интервјуа у књизи о рецепцији француске теорије, будући да се амерички теоретичар директно осврће на то како је Кисе тематизовао француску теорију и начин на који је она реципирана у Европи и Америци. Калер најпре истиче разлоге због којих сматра да је већ поменуто мишљење о занемаривању мислилаца ове оријентације у Француској у извесном смислу поједностављено, а затим додатно разрађује ову проблематику, истичући разлике у начинима на који је ова теоријска оријентација прихваћена у Француској и Америци, с интересантним освртом на рецепцију француске теорије у Кини. Тако аутор заступа тезу да је француска теорија у Француској доживљена као „систематичан, научни поступак за превазилажење старог буржоаског начина размишљања о писцима и њиховим остварењима“, а у Америци као „извор нових концепата за тумачење књижевних дела“ - извор окарактерисан као „постструктурализам“ којим се одбацује „научнички оријентисан“" структурализам (Аничић 2018: 14).

Поред Кисеове мисли, аутор овог осврта на француску теорију осврће се на читав низ теоретичара који заступају различите ставове о начину на који је француска теорија утицала на развој различитих теоријских усмерења у Америци, попут феминизма и студија рода. Интересантан допринос проблематици рецепције француске теорије Калер пружа и када говори о начину на који су текстови поменутих француских мислилаца присутни у наставној пракси на универзитетима, напомињући да се текстови француских теоретичара ипак и даље обрађују у оквиру различитих теоријских курсева на универзитетима у Америци. Иако напомиње да се може говорити о смањеном интересовању у Сједињеним Америчким Државама за темељне текстове француске теорије, Калер нас ипак у овом тексту уверава у то да француска теорија одговара његовој сопственој дефиницији теоријске делатности, коју налазимо на почетку текста: „теоријом се могу сматрати она дела која успевају да врше утицај и изван своје матичне дисциплине јер се њихове анализе језика, духа и идентитета или друштвене и политичке структуре показују плодоноснима у новим промишљањима других домена значења“ (Аничић 2018: 12-13).

Док су поменути текстови директно усмерени на разматрање различитих начина на који се француска теорија доживљава у Европи, Америци и Азији од тренутка њене највеће популарности до данас, може се рећи да се проблематика коју затичемо у наредним текстовима у књизи о рецепцији француске теорије у извесном смислу преображава у конкретнији теоријски задатак својеврсне демистификације француске теорије. У првом и другом делу текста насловљеног „Француска теорија у Америци”, теоретичар и јавни интелектуалац Стенли Фиш, најпознатији по својим текстовима у часописима попут New York Times 
(у коме су објављени и текстови са којима се сусрећемо у овој књизи) и Wall Street Journal, приступа проблему разумевања француске теорије уз помоћ разматрања деконструкције као једног од основних појмова овог теоријског усмерења (Fish 2008a, 2008b). Непосредан повод за настанак овог текста који је, судећи по критикама на које аутор реферише у другом делу истоименог текста, изазвао бурне реакције, представља превод Кисеове књиге о француској теорији на енглески, чиме се, још једном, књига о рецепцији француске теорије може читати и као разрада тематике обрађене у познатој књизи.

Фиш најпре реферише на одређену предисторију француске теорије показујући како је она у супротности са рационалистичким поуздањем у „разумске способности“ човека и Беконовим (Francis Bacon) веровањем у способност индуктивног закључивања (Аничић 2018: 28). Насупрот овим теоријским стремљењима, амерички интелектуалац истиче сличност између важности коју у француској теорији има анализа дискурса и одређених ставова Хобсове (Thomas Hobbes) политичке филозофије. Обраћајући се противницима француске теорије, којима је неприхватљив став да се не може говорити о „истини" мимо дискурзивне праксе, Фиш на интересантан начин наглашава да овде није реч о крајњем релативизовању мишљења: „То јесте губитак, али није губитак ничег конкретног. Не узима ништа од нас. Можемо и даље радити ствари које смо увек радили; можемо и даље рећи да су неке ствари истините, а неке лажне, и веровати у то. (...) Једино што губимо у извесном смислу (ако нас је убедила деконструктивистичка критика) јесте извесна рационална вера да ће једног дана постојати завршна реч, последњи опис стварности који ће ту стварност тачно приказати у потпуности“ (Аничић 2018: 30). Основни циљ ка коме Фиш тежи када говори о француској теорији на изложени начин јесте критика начина на који је француска теорија реципирана у Америци. Сматрајући, у сагласности са Кисеом, да се критичари француске теорије без јасног разлога устремљују на политичке последице које произилазе из овакве теоријске оријентације, Фиш наглашава да деконструкција просто не може инспирисати одређено политичко усмерење, будући да је она само ,једна епистемологија“, а преобраћена у „политичког покретача“, она може бити „само још једна позиција која чека властиту деконструкцију“ (Аничић 2018: 30, 31-32). Управо у овом задатку који Фиш себи намењује у тексту објављеном у часопису New York Times препознајемо тежњу ка демистификацији француске теорије.

Други део Фишовог текста „Француска теорија у Америци“ (Fish 2008b) настаје услед многобројних критика које су биле упућене првом делу, па је највећи део овог текста посвећен овој проблематици. Поред излагања бројних коментара који се тичу стила писања аутора француске теорије, а који Фиш није применио у свом тексту, па тиме није био „у стању да умакне чину наметања једног структуралистичког оквира“, амерички интелектуалац посебну пажњу посвећује наглашавању да епистемологија, као теорија сазнања, не утиче директно на ставове који су прихваћени као истинити (Аничић 2018: 35). Следствено томе, сматра Фиш, позивање на једну епистемолошку позицију (у овом случају, деконструктивистичку позицију) не одговара на свакодневно жи- 
вотно питање о томе због чега се одређени став сматра истинитим: „Ја могу да мењам епистемологије (...) али то мењање неће променити моје убеђење да је неко одређено ово или оно истинито“ (Аничић 2018: 38). Као таква, сматра Фиш, она не чини човека пријемчивијим за вредности једног политичког опредељења, попут веровања у важност толеранције, нити подстиче одређено делање у друштву (Аничић 2018: 40-41). Амерички интелектуалац завршава други део поменутог текста у духу приче о рецепцији француске теорије, сматрајући да је истицање наводне политичке улоге деконструкције заправо последица околности које је француска теорија, као популарно теоријско опредељење, тек случајно произвела (Аничић 2018: 42).

Последња два текста у књизи о рецепцији француске теорије долазе из пера аутора који припадају овој специфичној теоријској струји: Алена Бадијуа (Alain Badiou) и Мишела Фукоа. Уместо о француској теорији, Бадију у тексту предавања одржаног у Буенос Ајресу 2004. године говори о ширем спектру француске филозофије која је доживела успех током двадесетог века, спектру који он назива „француски филозофски тренутак” (Badiou 2004, 2005), па је преводилац текста искористио ову фразу за наслов преведеног текста, уместо оригиналног, "Panorama de la philosophie française contemporaine" (Аничић 2018: 57).

Поредећи период у француској филозофији који започиње Сартровим (Jean-Paul Sartre) Бићем и ништавилом, а завршава последњим Делезовим текстовима из деведесетих година прошлог века, са успоном античке филозофије од Парменида до Аристотела или класичним немачким идеализмом, Бадију у тексту обрађује четири важна аспекта француског филозофског тренутка. Први се тиче порекла овог периода у француској филозофији - Бадију сматра да су две упоришне тачке француске филозофије у 20. веку Бергсонова (Henri Bergson) „филозофија живота и постајања” и Бреншвикова (Léon Brunschvicg) „филозофија појма ослоњена на математику”, а да ове две тенденције уједињује интересовање француских филозофа за појам субјекта, што их онда приближава и старијој француској теоријској традицији оличеној у Декартовој (René Descartes) филозофији (Аничић 2018: 46-48). Други важан аспект који Бадију обрађује у овом тексту су заједничка теоријска интересовања различитих аутора који припадају француском филозофском тренутку - то су окретање немачкој филозофији, разумевање науке мимо апаратуре теорије сазнања, окретање филозофије политичкој проблематици и оно што француски филозоф назива „модернизацијом филозофије”, а огледа се у тежњи ка „уметничким, културним, друштвеним преображајима“ (Аничић 2018: 50). Трећи аспект који Бадију посебно истиче јесте приближавање филозофије књижевности, који француски филозоф не сматра новином већ специфичном карактеристиком француске културе, док као четврти аспект издваја важност психоанализе за ово теоријско опредељење, важност која је не само деривирана из актуелности ове дисциплине у 20. веку, него и из већ поменутог значаја појма субјекта за филозофију ове врсте. Иако није директно повезан са проблематиком рецепције француске теорије, интересантно је да Бадијуов текст заправо подстиче 
другачији поглед на ово теоријско опредељење, будући да показује да постоји одређени континуитет у француској филозофској традицији који је довео до појављивања специфичног теоријског правца за који се везује ова књига.

Текст којим се завршава књига о рецепцији француске теорије пре се може сматрати примером специфичног дискурса који се приписује овом теоријском опредељењу, него што се може тумачити као непосредно разматрање проблематике рецепције овог дискурса, па је разумљиво да је овај текст у садржају књиге пребачен у “Аppendix" (иако, зачудо издвојени “Аppendix“ не налазимо у самом тексту књиге). Ипак, да овај текст није потпуно удаљен од проблематике рецепције француске теорије, показује чињеница да је непосредан повод за његов настанак одређена критика која је била усмерена на различите теоријске поступке које се тичу појма аутора, а које је извршио у Речима и стварима: дакле, Фуко овим текстом дирекно одговара на начин на који је његово дело реципирано.

У тексту под називом „Шта је аутор?”, који представља његово приступно предавање на Колеж де Франсу (Collège de France) (Foucault 1969), француски филозоф најпре показује да је аутор одређеног дела данас аутореференцијалан, али да истовремено у свом делу „ишчезава”; он пореди ову ситуацију са тежњом ка бесмртности хероја која се остварује писањем епопеје са савременим „брисањем индивидуалних ствојстава” ауторског субјекта (Аничић 2018: 62). Разматрање појма аутора у духу изложене проблематике нужно води Фукоа у проблематизовање појма дела, до чијег ,,јединства” не досежемо уколико покушамо да га изведемо из чина писања самог аутора. Коначно, изложени проблеми француског филозофа нагоне да се позабави самим појмом писања. Њиме се, сматра Фуко, тек привидно обезбеђује бартовска (Roland Barthes) „смрт аутора”, будући да се „емпиријска обележја аутора” заправо само пребацују на неку „трансценденталну анонимност” ствараоца текста (Аничић 2018: 64). Међутим, оваквим теоријским чином бисмо се једноставно вратили на референтни систем трансценденталне филозофије, уз помоћ које се ови проблеми „решавају” једноставним проглашавањем априорних механизама из којих деривирамо њихово значење. У наставку Фуко разматра читав низ проблема које изазива појам аутора: околност да име аутора није сводиво на властито име, да има улогу класификатора текстова које приписујемо одређеном аутору, али и да се може формирати специфичан дискурс око одређеног аутора. Управо ће француски филозоф у закључку овог текста посебно истаћи да нам разматрање ових појмова доприноси самој анализи дискурса, будући да нам увиди које добијамо промишљањем начина на који приступамо самом аутору могу обелоданити одређена својства дискурса који спроводимо у додиру са његовим делима.

Кратак увод у рецуепцију “франиуске теорије” може се сматрати књигом која ће примарно бити значајна познаваоцима теоријског опредељења ове врсте, као и читаоцима Кисеове књиге French Theory, али би истовремено могла бити интересантна и онима који се први пут сусрећу са учењем ове врсте, будући да на различите начине маркира основне координате француске теорије. 
Ово је посебно случај са Фишовим разматрањем појма деконструкције и Бадијуовим прегледом основних мотива које узима у обзир поменуто теоријско опредељење. Са друге стране, за оне који нису сасвим упознати са теоријским обрасцима овог филозофског усмерења, специфичан стил теоретисања који негује Фуко у последњем тексту ове књиге могао би представљати одговарајућу илустрацију изазова који литература ове врсте поставља пред будућег читаоца.

\section{Литература}

Аничић, Дејан (прир.) (2018) Кратак увод у рецепщију „фрранщуске теорије“. Лозница: Карпос.

Badiou, Alain (2004) "Panorama de la philosophie française contemporaine", Conférence à la Bibliothèque Nationale de Buenos Aires - 1 juin 2004.

Badiou, Alain (2005) "The Adventure of French Philosophy", New Left Review 35 September/October: 67-77.

Culler, Jonathan (2014) "French Theory Revisited", Contemporary French and Francophone Studies 18 (1): 4-13.

DalMolin, Eliane \& Roger Célestin (2014) “Interview avec François Cusset", Contemporary French and Francophone Studies 18 (1): 14-17.

Fish, Stanley (2008a) "French Theory in America", The New York Times, April 6, 2008.

Fish, Stanley (2008b) "French Theory in America, Part Two", The New York Times, April 20, 2008.

Foucault, Michel (1969) “Qu'est-ce qu'un auteur ?”, Bulletin de la Société française de philosophie 63 (3) (juillet-septembre): 73-104. 